\title{
Method to measure injector opening and closing lag times
}

\begin{abstract}
The paper describes a method to measure injector opening and closing lag times based on measuring the vibration in the axis of movement of a valve. There are also some results of the studies on a plate injector. Analysing the measurements obtained, it is demonstrated that opening and closing lag times can be determined much more precisely by measuring vibration than by the method based on analysing gas pressure directly behind an injector. The authors have noted the greater repeatability of standard deviation expressed as the smaller standard deviation of the lag times specified and the easy application of this method for stand testing. Consequently, this method can determine these times in a simple and precise way.
\end{abstract}

Keywords: an injector, opening lag time, closing lag time, vibration

\section{Metoda pomiaru czasu opóźnienia otwarcia i zamknięcia wtryskiwacza gazu}

\begin{abstract}
W artykule przedstawiono metode pomiaru czasu opóźnienia otwarcia i zamknieccia wtryskiwacza oparta na pomiarze drgań w osi ruchu elementu zaworowego. Przedstawiono przykładowe wyniki badań wtryskiwacza płytkowego. Analizując pomiary stanowiskowe wykazano, że pomiar drgań pozwala na znacznie dokładniejsze określenie czasu opóźnienia otwarcia i zamknięcia wtryskiwacza w stosunku do metody opartej na analizie ciśnienia gazu bezpośrednio za wtryskiwaczem. Wykazano większa powtarzalność wyrażona mniejszym odchyleniem standardowym wyznaczonych czasów opóźnienia oraz łatwość w implementacji metody do badań stanowiskowych. Pozwala to na stosowanie tej metody do łatwego i precyzyjnego określania tychże czasów.
\end{abstract}

Słowa kluczowe: wtryskiwacz, czas opóźnienia otwarcia, czas opóźnienia zamknięcia, drgania

\section{Introduction}

Not only are more sophisticated control algorithms required, but also better actuators because of increasingly strict environmental requirements imposed on the automotive internal combustion engines that are converted into gaseous fuels [7]. This is due to the need for a very precise quality control of air - fuel mixture, and consequently the amount of gas administered. Such control is based on measuring the time a system needs to inject gasoline. Later on, this time is converted into the time to inject gas and includes the difference because of a physical state of fuel (gaseous fuel displaces more air than liquid fuel), the changes in demand for air during the combustion of both fuels, the difference in the dynamics of the mixture formation and the difference in the characteristics of the mass flow rates of petrol and gas injectors.

To obtain the required accuracy, it is necessary to comply with two requirements. The first one means the correct fitting of a system $[4,5]$ and the calibration of a control algorithm that recalculates gasoline injection time into gas injection time $[3,6]$. The second requirement concerns using a suitable actuator, i.e. an impulse gas injector. Both of them interact strongly. Using even the best injector without its appropriate algorithm and calibration will not satisfy the environmental and utility requirements. Nevertheless, even the best control algorithm will not be able to fix the faulty operation of an injector.

You can successfully optimise an injector design and match control algorithms to different types of injectors, if

\section{Wprowadzenie}

Rosnące wymagania ekologiczne dotyczące samochodowych silników spalinowych konwertowanych na zasilanie paliwami gazowymi [7] wymuszają stosowanie nie tylko coraz bardziej wyrafinowanych algorytmów sterowania, ale także coraz lepszych elementów wykonawczych. Wynika to z konieczności bardzo dokładnego sterowania jakością mieszanki paliwowo-powietrznej, a zatem ilością podawanego gazu. Sterowanie to odbywa się na podstawie pomiaru czasu wtrysku realizowanego przez układ benzynowy, przeliczanego następnie na czas wtrysku gazu, z uwzględnieniem: różnicy w stanie skupienia paliwa (wypieranie przez paliwo gazowe większej objętości powietrza niż w odniesieniu do paliwa płynnego), zmiany zapotrzebowania na powietrze podczas spalania obu paliw, różnicy w dynamice tworzenia mieszanki oraz różnicy w charakterystykach wydatku wtryskiwaczy benzyny i gazu.

Aby uzyskać wymaganą dokładność, konieczne jest spełnienie dwóch warunków. Pierwszym jest prawidłowy montaż układu [4, 5] i kalibracja algorytmu sterującego, przeliczającego czas wtrysku benzyny na czas wtrysku gazu $[3,6]$. Drugim natomiast jest zastosowanie odpowiedniego urządzenia wykonawczego, jakim jest impulsowy wtryskiwacz gazu. Oba warunki są ze sobą bardzo powiązane. $Z$ jednej strony - zastosowanie nawet najlepszego wtryskiwacza bez odpowiedniego algorytmu przeliczającego oraz jego kalibracji nie pozwoli na spełnienie wymagań ekologicznych i użytkowych. Z drugiej strony - nawet najlepszy algorytm 
you know their characteristics. Injector opening and closing lag times are relevant operating parameters $[1,2]$. As shown in the work [1], these times significantly influence the characteristics of an injector mass flow rate as they determine the intersection point of this characteristics with a time axis. It should be noted that the characteristics of the mass flow rate for petrol injectors intersects a time axis at 0 . Thus, if the intersection point of the characteristics of a gas injector mass flow rate is shifted from this value, a recalculation coefficient of a control algorithm, especially for short injection times (Fig. 1) becomes significantly non-linear.

Figure 1 shows the characteristics of a gasoline injector and two sample gas injectors. These are typical characteristics of components used for gaseous power systems. Typically, the intersection point of the characteristics of gas injectors with a time axis the is shifted within negative values. This is mainly due to the relatively much inertia of an armature and a large amount of energy in a coil during injection [1].

Figure 1 shows also the time course of the conversion factor $\mathrm{k}_{\mathrm{a}}$ as a function of the petrol injection time $\mathrm{t}_{\text {inj_gasoline }}$ for both types of injectors. As showed in the figure below, the shift of the characteristics of an injector so as the intersection point of its extension with a time axis could move from about -0.8 to about -1.3 changes the recalculation coefficient $\mathrm{k}$ from maximal 2.3 to 5.0 and an injection time of $2.0 \mathrm{~ms}$ from 1.27 to 0.94 . Thus, the measurement error for low injection times (due to the contrains of the control system design) significantly impacts the accuracy of fuel dosing as it is amplified by the recalculation coefficient.

The key information to develop a recalculation coefficient, or to properly calibrate a control system is the intersection point of the characteristics of an injector mass flow rate with a time axis. As shown in the work [1], it is possible to specify this point just by analysing injector opening and closing lag times:

$$
\mathrm{t}_{0}=\mathrm{t}_{\mathrm{op}}-\mathrm{t}_{\mathrm{cl}}
$$

where: $t_{0}$ - the intersection point of the characteristics of an injector mass flow rate with a time axis, $t_{o p}$ - injector opening lag time - the time between beginning a control signal and real opening of a injector valve, $\mathrm{t}_{\mathrm{cl}}$ - injector closing lag time - the time between finishing a control signal and real closing of a injector valve.

As a result, it is necessary to precisely specify injector opening and closing lag times. The method to measure them must be possible under operating conditions (or similar) and cannot change the characteristics of injector performance. For this assumption and the injector construction (a valving element is inside the injector), it is not possible to use the methods to measure directly the position of a valving element.

Therefore, indirect methods are used. The one used currently is based on analysing the gas pressure directly behind an injector [1]. This method works well for measuring injector opening lag time. However, it is difficult to sterowania nie będzie w stanie skorygować błędów działania wtryskiwacza.

Optymalizacja konstrukcji wtryskiwaczy oraz dopasowania algorytmów sterowania do poszczególnych typów wtryskiwaczy wymaga wiedzy o ich charakterystyce. Istotnymi parametrami pracy wtryskiwacza są czas opóźnienia otwarcia i czas opóźnienia zamknięcia $[1,2]$. Jak wykazano w pracy [1] czasy te znacząco wpływają na charakterystykę wydatku wtryskiwacza, determinując położenie punktu przecięcia się charakterystyki wydatku wtryskiwacza z osią czasu. Należy zwrócić uwagę, że wtryskiwacze benzyny mają charakterystykę wydatku przecinającą oś czasu w 0. Zatem wszelkie przesunięcia punktu przecięcia charakterystyki wydatku wtryskiwacza gazu od tej wartości powodują znaczną nieliniowość współczynnika przeliczeniowego algorytmu sterującego, szczególnie w obszarze małych czasów wtrysku (rys. 1).

Na rysunku 1 przedstawiono charakterystyki wtryskiwacza benzyny oraz dwóch przykładowych wtryskiwaczy gazu. Są to typowe charakterystyki elementów wykorzystywanych w układach zasilania silnika paliwami gazowymi. Charakterystyczną cechą większości konstrukcji wtryskiwaczy gazowych jest przesuniecie punktu przecięcia przedłużenia ich charakterystyk $\mathrm{z}$ osią czasu $\mathrm{w}$ wartościach ujemnych. Wynika to przede wszystkim ze stosunkowo dużej bezwładności ruchu zwory oraz dużej ilości energii gromadzonej w cewce w czasie wtrysku [1].

Na rysunku 1 przedstawiono także przebieg współczynnika przeliczeniowego $\mathrm{k}_{\mathrm{a}} \mathrm{w}$ funkcji czasu wtrysku benzyny $\mathrm{t}_{\text {inj gasoline }} \mathrm{dla}$ obu wtryskiwaczy gazowych. Przedstawione na tym rysunku przesunięcie charakterystyki wtryskiwacza, tak aby punkt przecięcia jej przedłużenia z osią czasu wtrysku przesunął się z około - 0,8 do około -1,3, powoduje zmianę współczynnika przeliczeniowego $\mathrm{k}_{\mathrm{a}} \mathrm{z}$ maksymalnie 2,3 na 5,0, a przykładowo przy czasie wtrysku 2,0 ms z 1,27 na 0,94 . Zatem przy małych czasach wtrysku błąd jego pomiaru (występujący w wyniku ograniczeń konstrukcyjnych układu sterowania) znacząco wpływa na dokładność dawkowania paliwa, gdyż jest wzmacniany przez współczynnik przeliczeniowy.

Znajomość punktu przecięcia charakterystyki wydatku wtryskiwacza z osią czasu jest kluczową informacją potrzebną do opracowania współczynnika przeliczeniowego, czyli do prawidłowej kalibracji systemu sterowania. Jak wykazano w pracy [1], wyznaczenie tego punku jest możliwe bezpośrednio na podstawie analizy czasów opóźnienia otwarcia i zamknięcia wtryskiwacza:

$$
\mathrm{t}_{0}=\mathrm{t}_{\mathrm{op}}-\mathrm{t}_{\mathrm{cl}}
$$

gdzie: $\mathrm{t}_{0}$ - punkt przecięcia charakterystyki wydatku wtryskiwacza $\mathrm{z}$ osią czasu wtrysku, $\mathrm{t}_{\mathrm{op}}$ - czas opóźnienia otwarcia wtryskiwacza - czas miedzy rozpoczęciem sygnału sterującego a rzeczywistym otwarciem zaworu wtryskiwa$\mathrm{cza}, \mathrm{t}_{\mathrm{cl}}$ - czas opóźnienia zamknięcia wtryskiwacza - czas między zakończeniem sygnału sterującego a rzeczywistym zamknięciem zaworu wtryskiwacza. 
measure closing lag time due to the inertia of the gas flow in a measurment system [1].
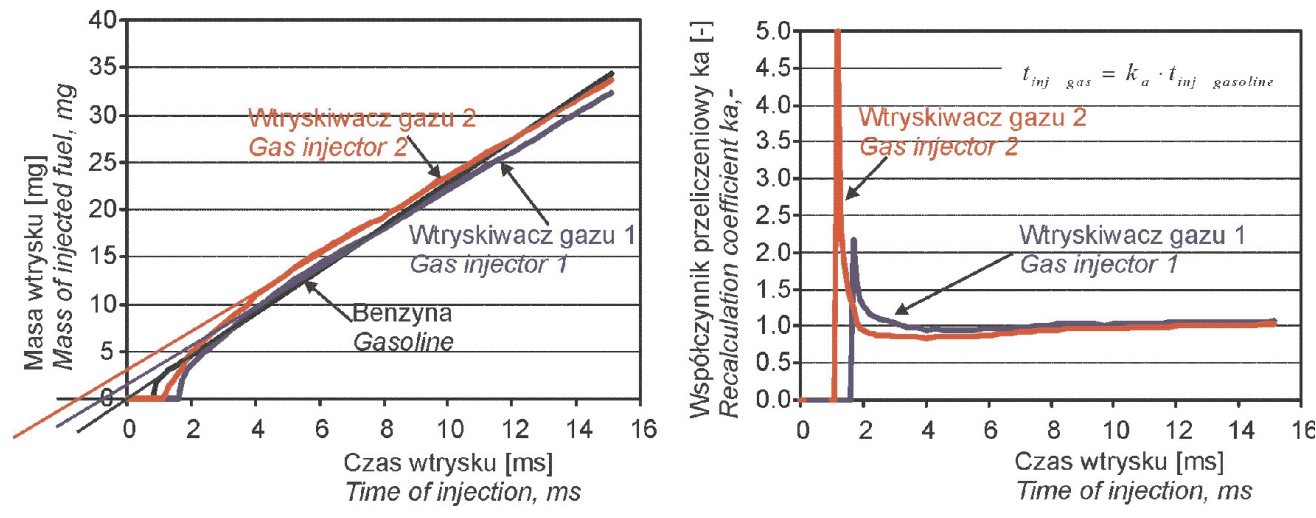

Fig. 1. Influence of the gas injection flow characteristic on the recalculation coefficient Rys. 1. Wplyw charakterystyki wtryskiwacza gazu na wspótczynnik przeliczeniowy

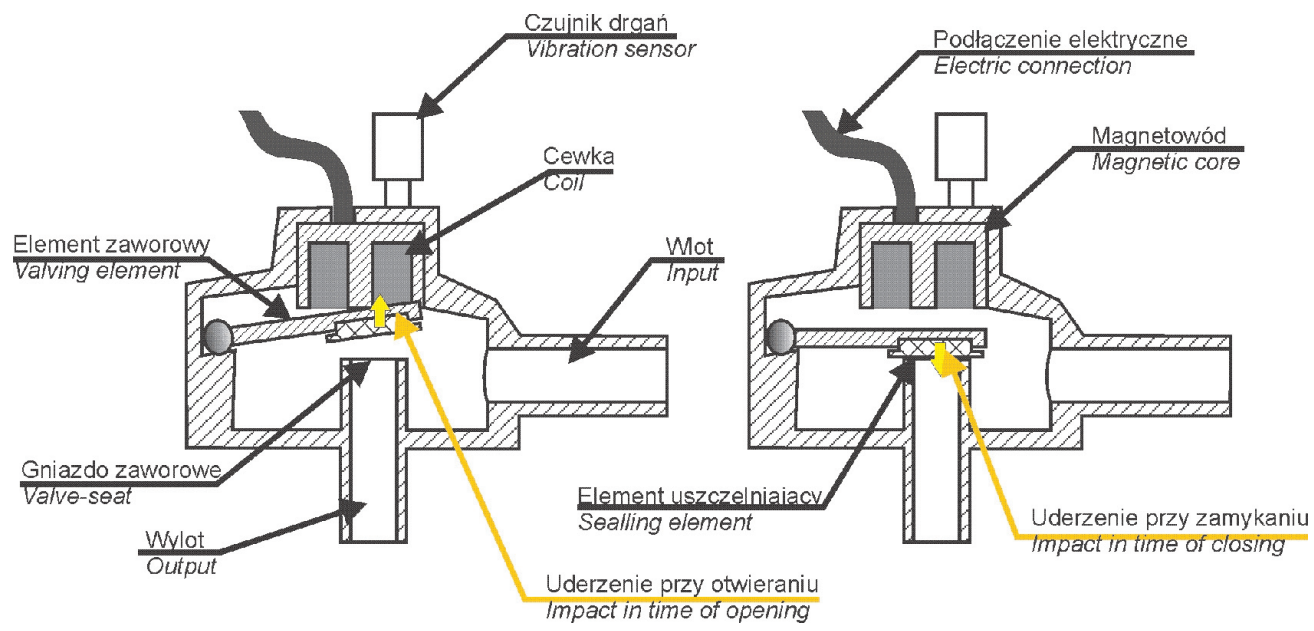

Fig. 2. Scheme of the injector design and the measurement methods Rys. 2. Schemat budowy wtryskiwacza oraz metody pomiaru
Powstaje zatem potrzeba dokładnego wyznaczania czasu opóźnienia otwarcia i zamknięcia wtryskiwacza. Metoda pomiaru tych czasów musi być możliwa do zastosowania w warunkach eksploatacyjnych (bądź do nich zbliżonych), a jednocześnie nie może zmieniać charakterystyki pracy wtryskiwacza. Ze względu na powyższe założenie oraz konstrukcję wtryskiwacza (element zaworowy znajduje się wewnątrz wtryskiwacza) nie jest możliwe zastosowanie metod bezpośredniego pomiaru położenia elementu zaworowego. Dlatego stosowane są metody pośrednie. Obecnie stosowaną metodą [1] jest analiza ciśnienia gazu bezpośrednio za wtryskiwaczem. Metoda ta sprawdza się przy pomiarze czasu opóźnienia otwarcia, natomiast pomiar opóźnienia zamknięcia jest utrudniony ze względu na bezwładność przepływu gazu w układzie pomiarowym [1].

\section{Assumptions for the new method to measure lag time}

By analyzing the design of most injectors, it can be noted that a valving element (rod, plate or tab) moves from one resistance point to another, usually along the axis of gas outflow. Its movement is limited by the element of a coil magnetic circuit (i.e. a magnetic core, pin, coil carcass, etc.) and a valve seat. Thus, it can be assumed that the impact occurs when the valving element reaches the two extreme positions (Fig. 2).

It should be noted that for these extreme positions, there are no damping elements in the injector that would slow the movement of the valving element before it reaches its extreme position. Some injectors only have a rubber sealing element on the valving element placed from the side of the valve seat that absorbs the impact of a valving element against the valve seat.

By analysing the considerations, it can be assumed that the impact of the valving element against both the valve seat

\section{Założenia nowej metody pomiaru czasu opóźnienia}

Analizując konstrukcje większości wtryskiwaczy, można zauważyć, że element zaworowy (w postaci trzpienia, płytki lub klapki) porusza się od jednego do drugiego punktu oporowego najczęściej po osi wypływu gazu. Z jednej strony jego ruch ograniczony jest elementem obwodu magnetycznego cewki (magnetowodem, trzpieniem, karkasem cewki itp.), a $\mathrm{z}$ drugiej strony gniazdem zaworu. Można zatem przypuszczać, że w momencie dotarcia elementu zaworowego do obu skrajnych położeń wystąpi uderzenie (rys. 2).

Jednocześnie należy zauważyć, że w konstrukcji wtryskiwacza nie istnieją w tych skrajnych położeniach elementy thumiące - zwalniające ruch elementu zaworowego przed dotarciem do skrajnego położenia. Jedynie w niektórych wtryskiwaczach, od strony gniazda zaworowego na elemencie zaworowym znajduje się gumowy element uszczelnienia, stanowiący element amortyzacji przy uderzeniu elementu zaworowego w gniazdo zaworu. 
and the element of the electromagnetic circuit will make the injector design vibrate. Thus, these vibrations can be measured by such a vibration sensor mounted on the axis of the movement of the valving element. The beginning of this vibration and not its amplitude and frequency will be important for the analysis. It should also be noted that for metal components (e.g. the body of an injector or a magnetic core) the measurement error between the real impact and its recording with a vibration sensor is minimal due to the small distance between the valving element and the sensor (about $20 \mathrm{~mm}$ on average) and high wave propagation velocity (about $4900 \mathrm{~m} / \mathrm{s}$ ). Accordingly, the lag should not be more than $0.004 \mathrm{~ms}$.

To sum up, by measuring the vibration in the axis of the movement of the valving element it should be possible to specify precisely the moment of the impact of the valving element against the magnetic circuit element to determine opening lag time as a control impulse is measured at the same time, and the moment of the impact of this valving element against the valve seat to determine closing lag time.

\section{Research stand and object}

\subsection{Research stand}

The research was conducted on the test bench, shown in Figure 3 which consists of an air handling system, an injector section and measurement systems. The air handling system includes a piston compressor, an air dehumidifier, and a membrane input pressure regulator. This system brings air into the injector section where the injector and measurement systems are mounted.

The stand is equipped with a research control unit developed at the Lublin University of Technology that controls the injector with any frequency, injection duration and time course of current. As a result, a wide range of tests on gas injectors can be done.

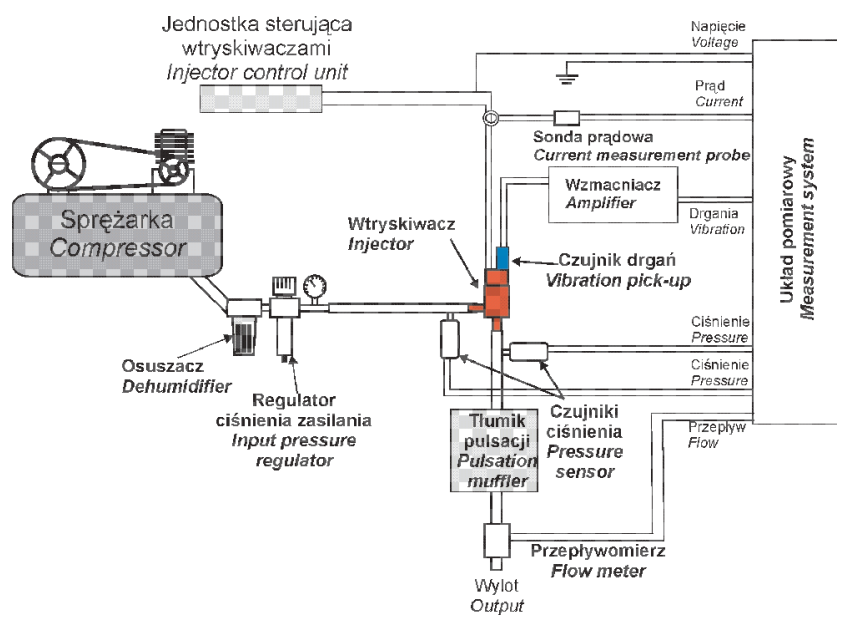

Fig. 3. Test stand

Rys. 3. Stanowisko badawcze

The test bed was equipped with the measurement system NI-9178 CompactDAQ cDAQ by National Instruments with the data acquisition cards NI 9215 that enable the simultane-
Analizując powyższe rozważania, można przypuszczać, że uderzenie elementu zaworowego zarówno w gniazdo zaworowe, jaki i element obwodu elektromagnetycznego wywoła w konstrukcji wtryskiwacza drgania. Montując zatem czujnik drgań w osi ruchu elementu zaworowego, będzie można zarejestrować te drgania. Do analiz istotny będzie ich początek, a nie amplituda i częstotliwość. Należy także zauważyć, że dla elementów wykonanych z metalu (np. korpus wtryskiwacza lub magnetowodu) błąd pomiaru pomiędzy rzeczywistym uderzeniem a jego rejestracją przez czujnik drgań jest minimalny ze względu na małą odległość miedzy elementem zaworu a czujnikiem (przeciętnie około $20 \mathrm{~mm}$ ) oraz dużą prędkość rozchodzenia się fali (około $4900 \mathrm{~m} / \mathrm{s}$ ). Zatem opóźnienie nie powinno być większe niż $0,004 \mathrm{~ms}$.

Podsumowując zatem, pomiar drgań w osi ruchu elementu zaworowego powinien pozwolić na precyzyjne określenie chwili uderzenia tego elementu w element obwodu magnetycznego - co przy jednoczesnym pomiarze sygnału sterującego pozwoli na określenie czasu opóźnienia otwarcia oraz chwili uderzenia tego elementu w gniazdo zaworu - a to pozwoli na określenie czasu opóźnienia zamknięcia.

\section{Stanowisko badawcze i obiekt badań}

\subsection{Stanowisko badawcze}

Badania przeprowadzono na stanowisku badawczym przedstawionym na rysunku 3. Stanowisko to składa się z układu przygotowania powietrza, sekcji wtryskiwacza oraz układów pomiarowych. Układ przygotowania powietrza obejmuje sprężarkę tłokową, osuszacz powietrza oraz membranowy regulator ciśnienia zasilania. Układ ten doprowadza powietrze do sekcji wtryskiwaczowej, w której zamocowany jest badany wtryskiwacz oraz układy pomiarowe.

Stanowisko wyposażone jest w badawczą jednostkę sterującą, opracowaną na Politechnice Lubelskiej, pozwalającą na sterowanie wtryskiwaczem z dowolną częstotliwością, długością trwania impulsu wtrysku oraz przebiegiem prądu. Pozwala to na przeprowadzenie szerokiego zakresu badań wtryskiwaczy gazowych.

$\mathrm{Na}$ stanowisku zamontowano układ pomiarowy firmy National Instruments NI CompactDAQ cDAQ-9178 z kartami pomiarowymi NI 9215, umożliwiającymi pomiar symultaniczny sygnałów napięciowych z częstotliwością do $100 \mathrm{kHz}$. Podczas badań mierzono symultanicznie:

- sygnał sterujący - mierzony bezpośrednio przez kartę pomiarową,

- prąd w obwodzie cewki wtryskiwacza - mierzony za pomocą sondy prądowej Tektronix TCP305 wraz ze wzmacniaczem TCPA300,

- ciśnienie przed wtryskiwaczem (ciśnienia zasilania) - mierzone za pomocą czujnika MPX5700 o zakresie pomiarowym od 0 do $700 \mathrm{kPa}$ ciśnienia bezwzględnego, umieszczonego $100 \mathrm{~mm}$ przed wlotem do wtryskiwacza, - ciśnienie za wtryskiwaczem - mierzone za pomocą czujnika MPX4250 o zakresie pomiarowym od 0 do $250 \mathrm{kPa}$ ciśnienia bezwzględnego, umieszczonego w odległości 25 mm za wyjściem z wtryskiwacza, 
ous measurement of voltage signals with a frequency of up to $100 \mathrm{kHz}$. During the tests the simultaneously measured quantities included:

- a control signal - measured directly with the data acquisition,

- current in the injector coil circuit - measured with the current sensor Tektronix TCP305 with the amplifier TCPA300,

- before-injector pressure (input pressure) - measured with the sensor MPX5700 of a measuring range from 0 to 700 $\mathrm{kPa}$ of absolute pressure, mounted $100 \mathrm{~mm}$ before the injector inlet,

- behind-injector pressure - measured with the sensor MPX4250 of a measuring range from 0 to $250 \mathrm{kPa}$ of absolute pressure, mounted $25 \mathrm{~mm}$ behind the injector outlet,

- vibration along the axis of the movement of the injector valve - measured with the sensor PCB M353B12 of a sensitivity of $5.50 \mathrm{mV} / \mathrm{g}$ with the amplifier ECElectronics VibAMP PA-3000.

At the same time mass air flow was measured with the FESTO SFE3 air flow meter. The meter was mounted behind the element of a pulsation damper to obtain a stable value during the test which is the mean injector mass flow rate.

During the measurements all the sensors were supplied with a laboratory power supply that keeps constant voltage.

\subsection{Research object}

The study was conducted on an experimental injector developed by the authors (Fig. 4). The injector is of a plate design - its a valving element resembles a plate moving perpendicular to the axis of gas outflow (Fig. 5). The plate works also as the armature magnetic circuit and the valving element with a rubber sealing element. The movement of the valving element is limited by the lower surface of the magnetic core and surface of the valve seat, from above and from below respectively.

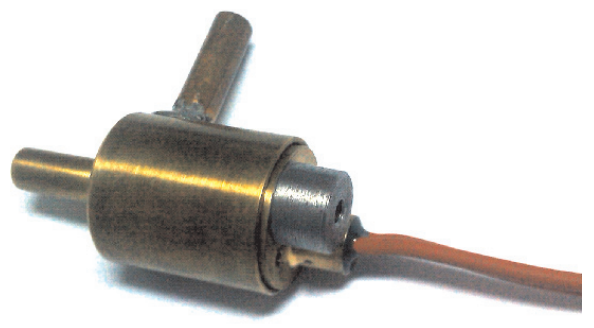

Fig. 4. Research object Rys. 4. Obiekt badań

The injector is equipped with an electromagnetic coil of a resistance of $2.4 \Omega$. The vibration sensor is mounted on the upper body of the injector (Fig. 4) to measure the vibration in the movement axis of the valving element.

\subsection{Research objective and scope}

The objective was to validate a method to determine injector opening and closing lag times based on analys-
- drgania w osi ruchu elementu zaworowego wtryskiwacza - mierzone za pomocą czujnika PCB M353B12 o czułości $5,50 \mathrm{mV} / \mathrm{g}$ wraz ze wzmacniaczem ECElectronics VibAMP PA-3000.

Jednocześnie dokonywano pomiaru masowego przepływu powietrza za pomocą przepływomierza powietrza firmy FESTO serii SFE3. Przepływomierz zabudowano za elementem tłumika pulsacji, tak aby podczas badań uzyskiwać stabilną wartość, będącą wartością uśrednionego wydatku wtryskiwacza.

Wszystkie czujniki zasilane były z zasilacza laboratoryjnego, utrzymującego stałe napięcie zasilania w czasie pomiarów.

\subsection{Obiekt badań}

Badania przeprowadzono na eksperymentalnym wtryskiwaczu opracowanym przez autorów niniejszego artykułu (rys. 4). Wtryskiwacz ten jest konstrukcji płytkowej - posiada element zaworowy w postaci płytki poruszającej się prostopadle do osi wypływu gazu (rys. 5). Płytka stanowi jednocześnie zworę obwodu magnetycznego oraz element zaworowy wyposażony w gumowy element uszczelniający. Ruch elementu zaworowego ograniczony jest od góry powierzchnią dolną magnetowodu, a ruch w dół ograniczony jest powierzchnią gniazda zaworowego.

Wtryskiwacz wyposażony jest w cewkę elektromagnetyczną o rezystancji $2,4 \Omega$.

Czujnik drgań zamocowano na górnej części korpusu wtryskiwacza (rys. 4), tak aby mierzył drgania w osi ruchu elementu zaworowego.

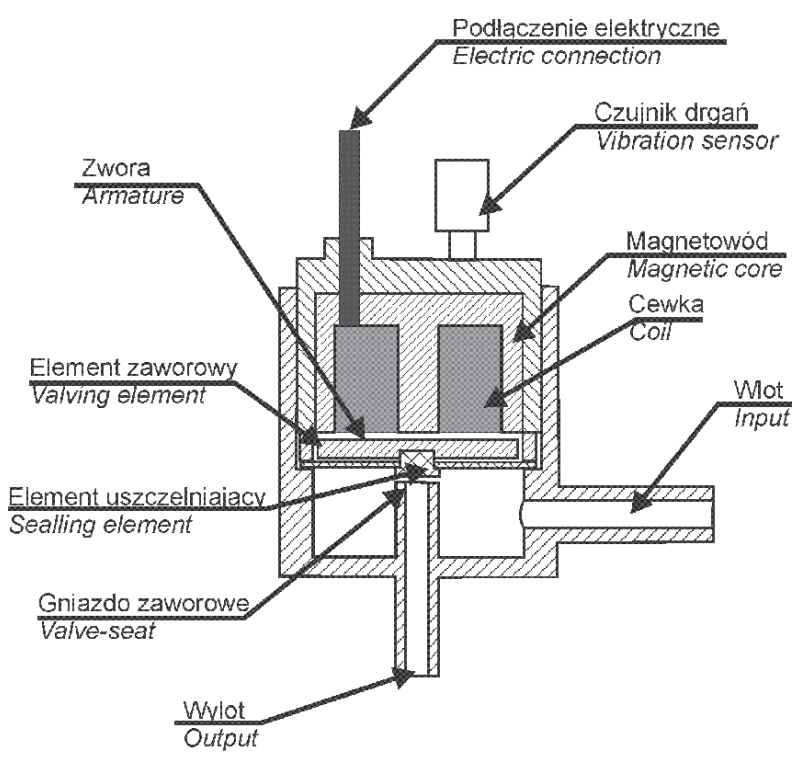

Fig. 5. Scheme of the research object

Rys. 5. Schemat konstrukcji obiektu badań

\subsection{Cel i zakres badań}

Celem badań było sprawdzenie poprawności metody wyznaczania czasów opóźnienia otwarcia i zamknięcia wtryskiwaczy na podstawie analizy drgań oraz porównanie jej wyników do wyników metody obecnie stosowanej, opartej na analizie ciśnienia za wtryskiwaczem. 
ing vibration and comparing these results with the results obtained by the current methods where the pressure behind the injector is analysed.

The research conditions were as follows:

a) the injector supply pressure: $240 \mathrm{kPa}$,

b) medium: air,

c) the frequency of injections: $12.5 \mathrm{~Hz}$,

d) control:

- supply: 12V DC stabilized

- constant impulse time: $2.0 \mathrm{~ms}$

- pulse-width modulation duty cycle: $30 \%$

- pulse-width modulation frequency: $10 \mathrm{kHz}$.

The scope of research included:

a) impulse duration (injection time): 3.0 and $10.0 \mathrm{~ms}$,

b) measuring frequency: $50 \mathrm{kHz}$ simultaneously,

c) recorded signals:

- control signal

- current in the coil circuit

- before-injector pressure

- behind-injector pressure

- vibration in the axis of movement of the valving element

d) subsequent recorded cycles: 300 .

\section{Method to specify lag times}

Figure 6 shows the courses of the behind-injector pressure, the current in the coil circuit and the vibration in the axis of the movement of the valving element that are averaged from the subsequent 300 cycles.

The start of the control signal coincides with the time of 0 as in the figure above. For the first about $0.8 \mathrm{~ms}$ the current in the coil increases only, while the pressure is constant. The vibration sensor records no accelerations. At point 1 , corresponding to approximately 0.81 $\mathrm{ms}$, the acceleration in the axis of the movement of the valving element is noted, which may indicate this element started moving. Then, there is noted the impact of the valving element against the magnetic coil (point 2) corresponding to the end of the opening of the valving element, and thus the injector opening lag time specified from the vibration $t_{\text {op }} v^{*}$ This time is $1.24 \mathrm{~ms}$.

At this point the change in the behind-injector pressure is still not registered. This change is noted at point 3 , corresponding to the injector opening lag time that is specified on the pressure $t_{o p}$. It is $1.54 \mathrm{~ms}$ and therefore is delayed by $0.3 \mathrm{~ms}$ with respect to the injector opening lag time specified on the vibration $t_{\text {op_v }}$. This delay is due to the inertia of the gas flow from the injector to the sensor that is about $25 \mathrm{~mm}$ away from the injector output.
Badania przeprowadzono w następujących warunkach:

a) ciśnienie zasilania wtryskiwacza $240 \mathrm{kPa}$,

b) medium: powietrze,

c) częstotliwość wtrysków $12,5 \mathrm{~Hz}$,

d) sterowanie:

- zasilanie: stabilizowane napięcie stałe $12 \mathrm{~V}$

- czas impulsu ciągłego 2,0 ms

- wypełnienie podtrzymania prądowego $30 \%$

- częstotliwość wypełnienia prądowego $10 \mathrm{kHz}$.

Zakres badań obejmowat:

a) czas impulsu sterującego (czas wtrysku): 3,0 i 10,0 ms,

b) częstotliwość pomiaru: symultanicznie $50 \mathrm{kHz}$,

c) rejestrowane sygnały:

- sygnał sterujący

- prąd w obwodzie cewki

- ciśnienie przed wtryskiwaczem

- ciśnienie za wtryskiwaczem

- drgania w osi ruchu elementu zaworowego

d) liczba zarejestrowanych kolejnych cykli: 300 .

\section{Metoda wyznaczania czasów opóźnienia}

Na rysunku 6 przedstawiono uśrednione z kolejnych 300 cykli przebiegi ciśnienia za wtryskiwaczem, prądu w obwodzie cewki oraz drgań w osi ruchu elementu zaworowego.

Początek sygnału sterującego pokrywa się z czasem 0 na rysunku 6. Przez pierwsze około $0,8 \mathrm{~ms}$ przyrasta jedynie prąd w cewce, natomiast ciśnienie jest na stałym poziomie, a czujnik drgań nie rejestruje żadnych przyspieszeń.

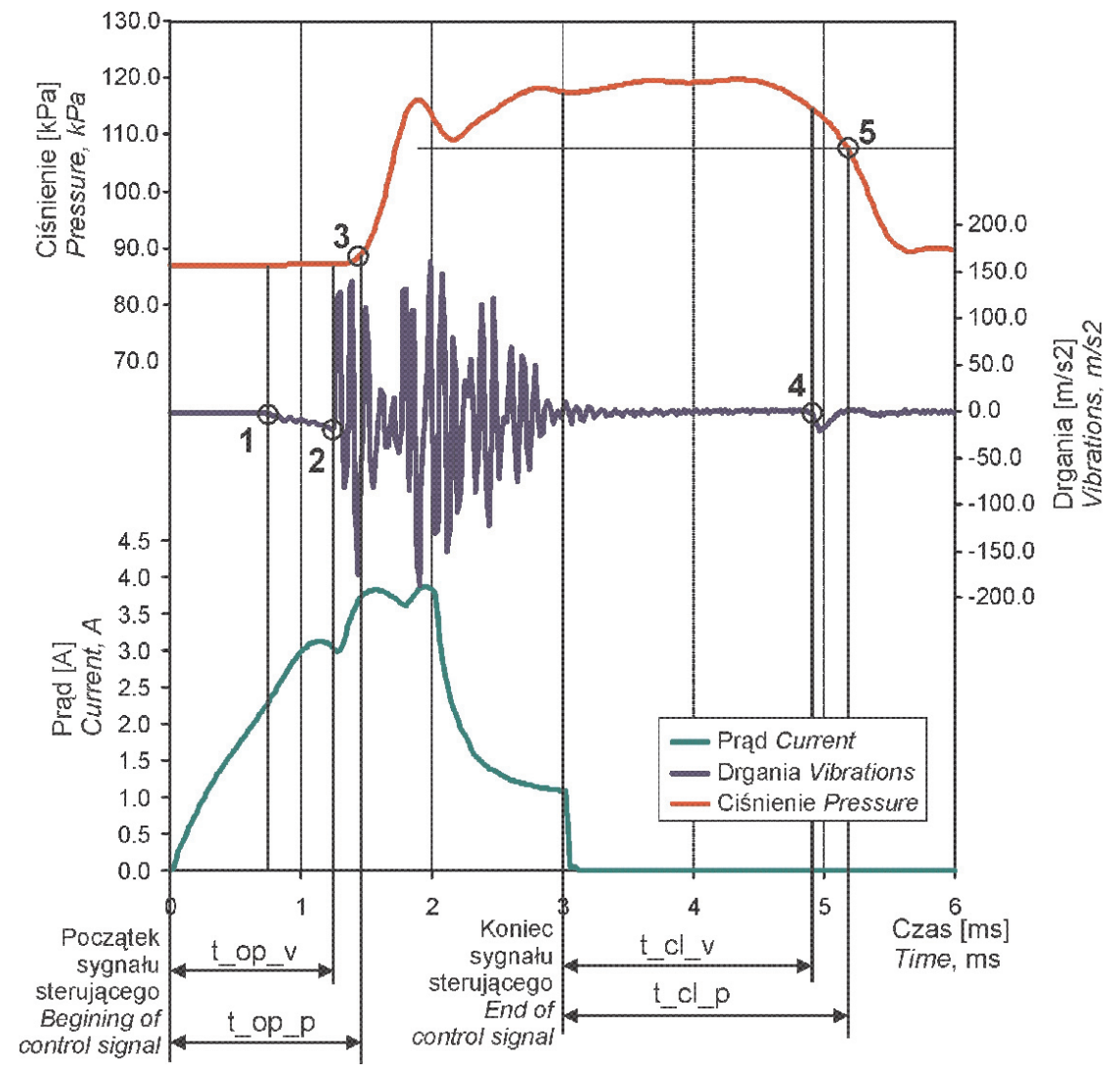

Fig. 6. Results for a control signal of $3 \mathrm{~ms}$

Rys. 6. Wyniki pomiarów przy czasie sygnatu sterującego $3 \mathrm{~ms}$ 
The control signal is turned off in $3 \mathrm{~ms}$, which is indicated by the current drop to 0 . However, gas is still flowing out of the injector, which is signalled by maintaining the behind-injector pressure. At point 4 the acceleration in the axis of the movement of the valving element is noted again, which means this element is moving. Therefore, this point determines the injector closing lag time, i.e. $1.97 \mathrm{~ms}$ set by the vibration $t_{\mathrm{cl} \mathrm{v}}$. It can be noted that this registered vibration is much smaller than for injector opening, which means that the impact of the valving element against the valve seat through the sealing element is damped.

The value of the injector closing lag time determined by pressure $t_{c l}$ is determined as the injector pressure drop below the lowest value recorded after it opens at point 5 . This value is $2.47 \mathrm{~ms}$ and is affected by both the error due to the gas flow inertia described and the method of the automatic determination of this time.

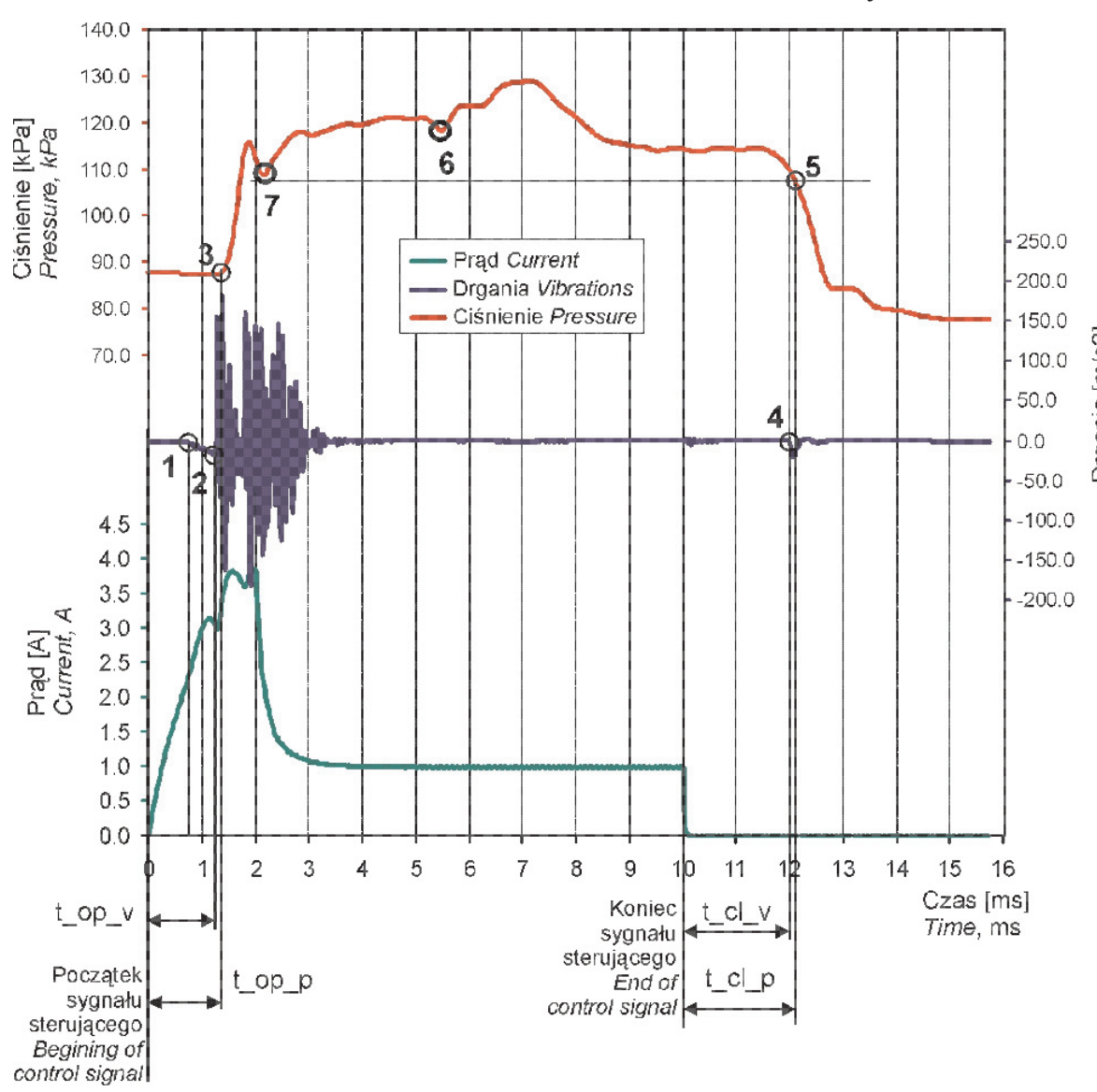

Fig. 7. Results for a control signal of $10 \mathrm{~ms}$

Rys. 7. Wyniki pomiarów przy czasie sygnału sterującego $10 \mathrm{~ms}$

W punkcie 1 , odpowiadającym około $0,81 \mathrm{~ms}$ widoczne jest pojawienie się przyspieszenia w osi ruchu elementu zaworowego, co może świadczyć o rozpoczęciu ruchu tego elementu. Następnie widoczne jest uderzenie elementu zaworowego o magnetowód cewki (punkt 2) odpowiadające zakończeniu otwierania się zaworu, a zatem czasowi opóźnienia otwarcia wtryskiwacza wyznaczonemu $\mathrm{z}$ drgań, $\mathrm{t}_{\mathrm{op} \text { v }}$. Wartość ta wynosi 1,24 ms.

W punkcie tym nadal nie jest rejestrowana zmiana ciśnienia za wtryskiwaczem. Widoczna jest ona dopiero w punkcie 3, odpowiadającym czasowi opóźnienia otwarcia

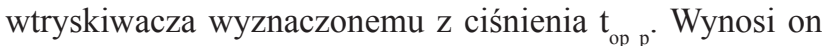
1,54 ms, a zatem jest opóźniony względem czasu opóźnienia otwarcia wtryskiwacza wyznaczonego $z$ drgań $t_{\text {op_v }} o$ 0,3 ms. Opóźnienie to wynika $z$ bezwładności przepływu gazu z wtryskiwacza do czujnika oddalonego od wyjścia wtryskiwacza o około $25 \mathrm{~mm}$.

W 3 ms następuje wyłączenie sygnału sterującego, co zaznacza się w spadku prądu do wartości 0 . Jednocześnie nadal występuje wypływ gazu z wtryskiwacza, co widoczne jest w utrzymaniu ciśnienia za wtryskiwaczem. W punkcie 4 widoczne jest ponowne wystąpienie przyspieszenia $\mathrm{W}$ osi ruchu elementu zaworowego świadczące o jego ruchu. Zatem punkt ten wyznacza na podstawie drgań $t_{c l ~ v ~}$ czas opóźnienia zamknięcia wtryskiwacza. Wynosi on 1,97 ms. Można zauważyć, że zarejestrowane drgania są znacznie mniejsze niż przy otwarciu wtryskiwacza, co świadczy o tłumieniu uderzenia elementu zaworowego w gniazdo zaworu przez element uszczelniający.

Wartość opóźnienia zamknięcia wtryskiwacza ustalona na podstawie ciśnienia $t_{\text {cl_p }}$ wyznaczana jest jako spadek ciśnienia za wtryskiwaczem poniżej najmniejszej wartości zarejestrowanej po jego otwarciu - punkt 5. Wartość ta wynosi 2,47 ms i jest obarczona zarówno błędem wynikającym z opisanej wcześniej bezwładności przepływu gazu,

Such a method to determine the algorithm of closing lag time has been adopted due to the time course of the beforeinjector pressure for longer times of a control signal (Fig. 7). In the system analysed (injector-test bed), the pressure drops instantaneously after about $3.5 \mathrm{~ms}$ of the actual opening of the injector (approx. $5.5 \mathrm{~ms}$ after the start of a control signal at point 6 ) and then increases again. Then, after about $3 \mathrm{~ms}$, the pressure falls below the local minimum that occurs jak i z metody automatycznego wyznaczania tego czasu.

Przyczyna przyjęcia do algorytmu takiej metody wyznaczania czasu opóźnienia zamknięcia wynika z przebiegu ciśnienia za wtryskiwaczem przy dłuższych czasach sygnału sterującego (rys. 7). W badanym układzie (wtryskiwacz-stanowisko) widoczny jest chwilowy spadek ciśnienia po około 3,5 ms rzeczywistego otwarcia wtryskiwacza (około 5,5 ms od rozpoczęcia sygnału sterującego - punkt 6), a następnie 
earlier (point 7). Therefore, it is assumed that the algorithm to specify the ending of gas outflow based on pressure relies on detecting a pressure drop below the local minimum that occurs at injector opening (the level that corresponds to point 7). It is therefore evident that closing lag time can be determined more precisely by analysing vibration.

\section{Research results}

300 consecutive cycles of the injector were analysed on the test bench. The opening and closing lag times for each cycle were determined by the two methods, i.e. based on pressure and vibration. Figure 8 shows the average values of those times for injection times of 3 and $10 \mathrm{~ms}$.

As noted, the average lag times specified by pressure and vibration are not identical. Lower values for both opening and closing lag times were specified by the vibration analysis. This difference of $0.30 \mathrm{~ms}$ for opening lag time is due to the inertia of the gas flow, or the time required for gas to flow from the injector valve to the point where pressure is measured (which is $25 \mathrm{~mm}$ away from the valve). For closing lag time, this difference is $0.42 \mathrm{~ms}$. This is due to both the above mentioned inertia $(0.30 \mathrm{~ms})$ and the error of the method to determine injector closing lag time based on a pressure analysis as described in Chapter 4, i.e. $0.12 \mathrm{~ms}$.

Figure 9 shows the standard deviation of injector opening and closing lag time obtained from 300 subsequent injection
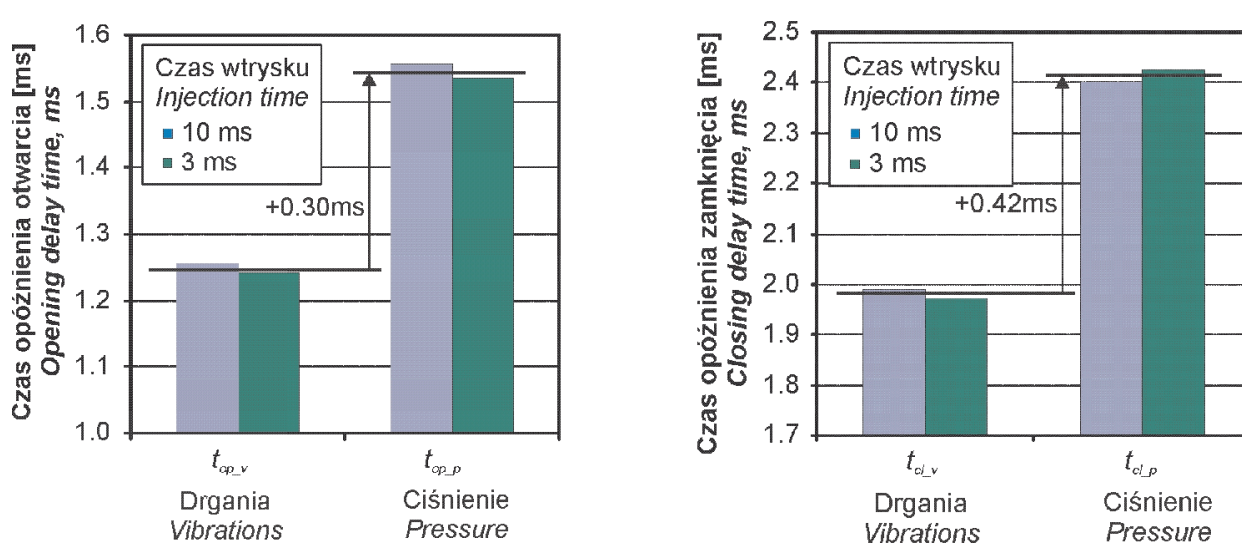

Fig. 8. Mean injection opening and closing lag times specified by pressure and vibration Rys. 8. Średni czas opóźnienia otwarcia i zamknięcia wtryskiwacza wyznaczony na podstawie ciśnienia i drgania
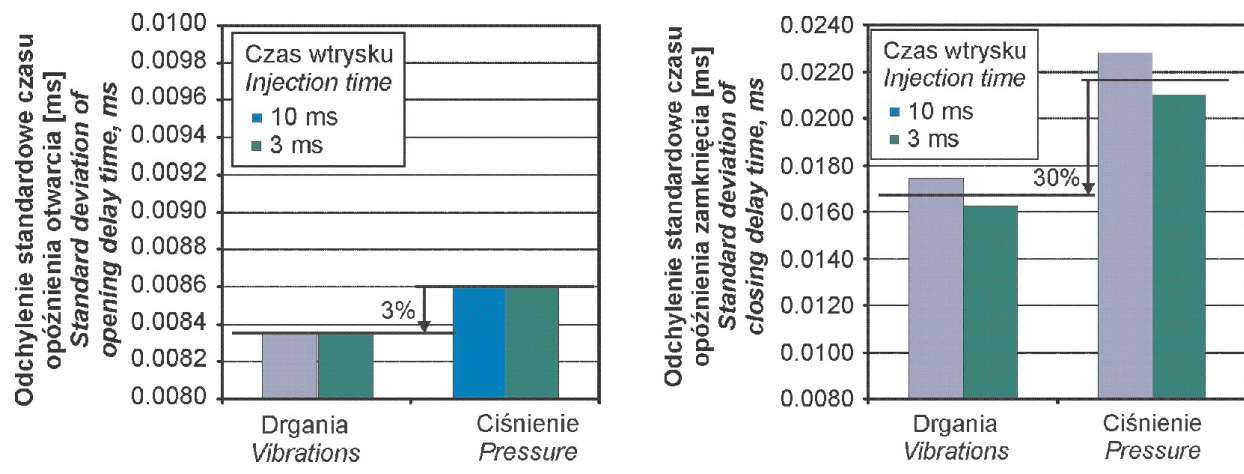

Fig. 9. Standard deviation of the injector opening and closing lag times determined by pressure and vibration Rys. 9. Odchylenie standardowe czasu opóźnienia otwarcia i zamknięcia wtryskiwacza wyznaczone na podstawie ciśnienia i drgania jego ponowny wzrost. Po około $3 \mathrm{~ms}$ ciśnienie spada do poziomu poniżej minimum lokalnego występującego wcześniej (punkt 7). Zatem przyjęto, że algorytm wyznaczania zakończenia wypływu gazu na podstawie ciśnienia bazuje na wykryciu spadku ciśnienia poniżej wartości minimum lokalnego występującego w czasie otwarcia wtryskiwacza (poziom odpowiadający punktowi 7). Widoczne jest zatem, że na podstawie analizy drgań możliwe jest bardziej precyzyjne wyznaczenie czasu opóźnienia zamknięcia wtryskiwacza.

\section{Wyniki badań}

W ramach badań przeprowadzono analizę kolejnych 300 cykli pracy wtryskiwacza na stanowisku badawczym. Dla każdego cyklu określono czasy opóźnienia otwarcia i zamknięcia wtryskiwacza metodami: opartą na analizie ciśnienia i opartą na analizie drgań. Na rysunku 8 przedstawiono średnie wartości tych czasów dla czasów wtrysku wynoszących odpowiednio 3 i $10 \mathrm{~ms}$.

Jak można zauważyć, średnie wartości czasów opóźnienia wyznaczonych na podstawie ciśnienia i drgań nie są jednakowe. Zarówno dla czasu opóźnienia otwarcia, jak i dla czasu opóźnienia zamknięcia mniejsze wartości wyznaczono na podstawie analizy drgań. W przypadku opóźnienia otwarcia różnica ta wynosi $0,30 \mathrm{~ms}$ i wynika z bezwładności przepływu gazu - czyli czasu potrzebnego do przepłynięcia gazu od zaworu we wtryskiwaczu do punktu pomiaru ciśnienia (w badaniach oddalonego od zaworu o około $25 \mathrm{~mm}$ ). W przypadku opóźnienia zamknięcia różnica ta wynosi już 0,42 ms. Wynika to zarówno z wyżej opisanego zjawiska bezwładności $(0,30$ ms) oraz z błędu metody określania chwili zamknięcia wtryskiwacza na podstawie analizy ciśnienia opisanej w rozdziale 4 (0,12 ms).

Rysunek 9 przedstawia wartości odchylenia standardowego czasów opóźnienia otwarcia i zamknięcia wtryskiwacza uzyskanych z kolejnych 300 cykli wtrysku. Jak można zauważyć, w obu przypadkach analiza sygnału drgań pozwoliła na uzyskanie wyników o większej powtarzalności (mniejszym odchyleniu standardowym). Dla czasu opóźnienia otwarcia różnica ta wynosi zaledwie 3\% i może być uznana za nieistotną, natomiast w przypadku czasu opóźnienia zamknięcia różnica ta wynosi aż 30\%. 
cycles. As seen, the vibration signal analysis made it possible to obtain results with greater repeatability (lower standard deviation) for the both cases. For opening lag time, this difference is only $3 \%$ and can be considered negligible, while for closing lag time is as high as $30 \%$.

\section{Summary}

By analysing the results, it can be concluded that:

1) the new method gives results comparable to those obtained by the standard method, but:

2) the method based on vibration measurements helps eliminate the error related to gas flow inertia, which increased the accuracy of specifying injector opening and closing lag times,

3) the greater repeatability of the analysis is obtained, which is signalled by smaller standard deviation. This is particularly evident in the case of injector closing lag time.

In conclusion, the proposed method allows easy and accurate measurement of injector opening and closing lag times without interfering with an injector construction.

\section{Podsumowanie}

Analizując wyniki można stwierdzić, że:

1) opracowana metoda daje wyniki porównywalne z uzyskiwanymi metodą standardową, lecz

2) metoda oparta na pomiarze drgań pozwoliła na wyeliminowanie błędu związanego z bezwładnością przepływu gazu, co zwiększyło dokładność wyznaczania czasów opóźnienia otwarcia i zamknięcia wtryskiwacza,

3) uzyskano większą powtarzalność wyników analizy widoczną w mniejszym odchyleniu standardowym. Widoczne jest to szczególnie w przypadku czasu opóźnienia zamknięcia wtryskiwacza.

Podsumowując, można stwierdzić, że proponowana metoda pozwala na łatwy i dokładny pomiar czasów opóźnienia otwarcia i zamknięcia wtryskiwacza bez ingerencji w konstrukcję wtryskiwacza.

Paper reviewed/Artykut recenzowany

\section{Bibliography/Literatura}

[1] Czarnigowski J.: The impact of supply pressure on gas injector expenditure characteristics, Combustion Engines (Silniki Spalinowe) 2/2010 (141), p. 18-26.

[2] Czarnigowski J., Wendeker M., Jakliński P., Rola M., Grabowski Ł., Pietrykowski K.: CFD model of fuel rail for LPG systems, SAE 2007-01-2053.

[3] Jakliński P., Czarnigowski J., Wendeker M.: The Effect of Injection Start Angle of Vaporized LPG on SI Engine Operation Parameters, SAE 2007-01-2054.

Prof. Mirosław Wendeker, DSc., DEng. - professor in the Faculty of Mechanical Engineering at Lublin University of Technology.

Prof. dr hab. inż. Mirostaw Wendeker - profesor na Wydziale Mechanicznym Politechniki Lubelskiej. e-mail:m.wendeker@pollub.pl

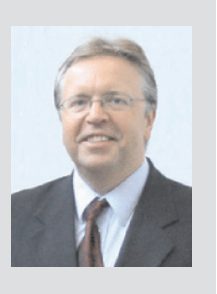

Mr. Jacek Czarnigowski, DEng. - doctor in the Faculty of Mechanical Engineering at Lublin University of Technology.

Dr inż. Jacek Czarnigowski - adiunkt na Wydziale Mechanicznym Politechniki Lubelskiej.

e-mail: j.czarnigowski@pollub.pl

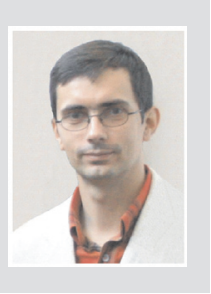

Mr. Grzegorz Barański, MEng. - technical worker in the Faculty of Mechanical Engineering at Lublin University of Technology

Mgr inż. Grzegorz Barański - pracownik techniczny na Wydziale Mechanicznym Politechniki Lubelskiej.

e-mail: g.baranski@pollub.pl
[4] Jakliński P., Grabowski Ł., Wendeker M., Czarnigowski J., Szczęsny P., Barański G., Sochaczewski R.: Analiza wpływu umieszczenia wtryskiwacza LPG na parametry pracy silnika o zapłonie iskrowym, PTNSS-2007-SS4-222, Silniki Spalinowe nr 4/2007, s. 33-41.

[5] Lee S., Kuswaka J., Daisho Y.: Mixture Formation and Combustion Characteristics of Directly Injected LPG Spray, SAE Technical Paper 2003-01-1917.

[6] Małek A, Wendeker M., Czarnigowski J., Grabowski Ł., Jakliński P., Barański G., Sochaczewski R., Podleśny M.: Stanowisko do badań prehomologacyjnych dla pojazdów wyposażonych w układ sekwencyjnego wtrysku gazu LPG, PTNSS CONGRESS-2007 P07-C148, Silniki Spalinowe PTNSS-2007-SC2.

[7] Regulamin nr 83 Europejskiej Komisji Gospodarczej Organizacji Narodów Zjednoczonych (EKG ONZ) - jednolite przepisy dotyczące homologacji pojazdów w zakresie emisji zanieczyszczeń w zależności od paliwa zasilającego silnik, Dziennik Urzędowy Unii Europejskiej L(legislacja) nr 119 z 6.5.2008, s. 1-181.

Mr. Mariusz Duk, DEng. - doctor in the Faculty of Electrical Engineering and Computer Science at Lublin University of Technology.

Drinż. Mariusz Duk-adiunkt na Wydziale Elektrotechniki i Informatyki Politechniki Lubelskiej. e-mail:m.duk@pollub.pl

Mr. Tomasz Zyska, MEng. - Laboratory assistant in the Faculty of Electrical Engineering and Computer Science at Lublin University of Technology.

Mgr inż. Tomasz Zyska - pracownik techniczny na Wydziale Elektrotechniki i Informatyki Politechniki Lubelskiej.

e-mail: t.zyska@pollub.pl 